\title{
Girls' secondary education in uganda: assessing policy within the women's empowerment framework
}

Shelley Jones

Aga Khan University, shelley.jones@aku.edu

Follow this and additional works at: http://ecommons.aku.edu/eastafrica_ied

Part of the Elementary and Middle and Secondary Education Administration Commons

\section{Recommended Citation}

Jones, S. (2011). Girls' secondary education in uganda: assessing policy within the women's empowerment framework. Gender and Education, 23(4), 385-413.

Available at: http://ecommons.aku.edu/eastafrica_ied/25 


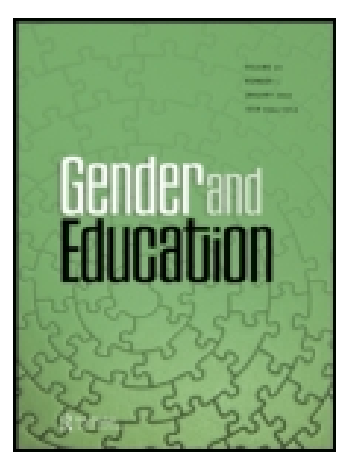

Gender and Education

\section{Girls' secondary education in Uganda: assessing policy within the women's empowerment framework}

\section{Shelley Kathleen Jones}

To cite this article: Shelley Kathleen Jones (2011) Girls' secondary education in Uganda: assessing policy within the women's empowerment framework, Gender and Education, 23:4, 385-413, DOI: 10.1080/09540253.2010.499854

To link to this article: http://dx.doi.org/10.1080/09540253.2010.499854

曲 Published online: 28 Jan 2011.

Submit your article to this journal $\widetilde{ }$

Џll Article views: 1296

Q View related articles $\longleftarrow$

4 Citing articles: 8 View citing articles ๘ 


\title{
Girls' secondary education in Uganda: assessing policy within the women's empowerment framework
}

\author{
Shelley Kathleen Jones* \\ Department of Curriculum and Instruction, School of Education and Professional Studies, \\ State University of New York, College at Potsdam, Potsdam NY 13676
}

(Received 13 November 2009; final version received 10 February 2010)

This paper makes the case that policies, such as the National Strategy for Girls' Education in Uganda (NSGE), intended to achieve gender equity in education for girls in developing countries, have limited relevance to, and impact on girls' actual educational experiences. Recent considerations of girls' education acknowledge that gender equity within education is more than access to schooling; it entails the cultivation of capabilities necessary for girls to participate fully, actively and equally in all aspects of their societies. Drawing on a longitudinal, ethnographic policy research case study with 15 Ugandan schoolgirls in rural Masaka District, Uganda, from August 2004 to September 2006, I explore the girls' educational experiences in relationship to the NSGE. I employ the Women's Empowerment Framework (WEF) to evaluate the NSGE with respect to the extent to which its interventions are 'empowering' for girls.

Keywords: development studies; equality; girls; ethnography; secondary education; Sub-Saharan Africa

\section{Girls' education: a priority in need of clarification}

Gender equity within education has become an international goal: 'Eliminating gender disparity in primary and secondary education by 2005 , and achieving gender equality in education by 2015 , with a focus on ensuring girls' full and equal access to and achievement in basic education of good quality' (UNESCO 2000, 8) is one of the six Education for All (EFA) goals that was articulated at the International Education Forum in Dakar in 2000. Gender equity is also embodied in Millennium Development Goals (MDGs) 2 and 3, which are committed respectively to universal primary schooling for all children in the world by 2015 , and the eradication of gender disparity in education. These global objectives around girls' education have prompted developing countries, such as Uganda, to establish policies concerning girls' education. Uganda's National Strategy for Girls' Education (NSGE) is such a policy.

Providing girls with 'education' is generally hailed as an unequivocal good; the corresponding assumption being that the greater the number of girls enrolled in school the greater the progress towards achieving gender-equitable education. However, several studies concerned with girls' educational opportunities have exposed the complex and multiple ways in which educational content, delivery and environment perpetuate and even generate gender inequities (Dunne, Humphries, and Leach 2003;

*Email: jonessk@potsdam.edu 
Jones 2008; Kakuru 2006; Kwesiga 2002; Leach 2003a; Leach et al. 2003; Longwe 1998; Mirembe and Davies 2001; Sperandio 2000; United Nations Development Programme 2005; UNESCO Institute for Statistics 2005; World Economic Forum 2005). These studies demonstrate the need for a deeper, more holistic understanding of the ways in which education intersects with girls' lives, as well as a need for critical evaluation of existing policies concerned with girls' education.

This article responds to these needs by considering the extent to which Uganda's NSGE has supported the empowerment of a cohort of Ugandan secondary schoolgirls in a rural community, using the ethnographic policy research approach within a postcolonial critical feminist paradigm. Ethnographic policy research approach (Levinson and Sutton 2001; Shore and Wright 1997; Vavrus 2005) can make both valuable and central contributions to critical policy assessment, as well as to effective future policies, by exploring the multiple complexities of the contexts in which policy is targeted to have an impact because it draws upon real-life experiences of those for whom policy is intended. With respect to girls' education in contexts such as rural Uganda, policies must be informed by the expressed needs of girls, considered within a postcolonial critical feminist paradigm that places strong emphasis on equity and empowerment. My understanding of empowerment for girls and women is guided by Longwe's definition:

women's empowerment is the process by which women collectively come to recognize and address the gender issues that stand in the way of their advancement. In a patriarchal society, these gender issues are the practices of gender discrimination which are entrenched in custom, law, and ideological belief. $(1998,19)$

The participants of my study were a cohort of 15 adolescent girls who attended secondary school in a poor, rural area of Masaka District. Data collected over a year (August 2004 to August 2005) include semi-structured interviews, questionnaires, focus group discussions and participation observation approaches. The research question to be addressed in this article is: To what extent has the NSGE achieved its objective of achieving quality, gender-equitable educational opportunities for girls that will enable them to 'to attain their maximum potential as equal and effective citizens' (Ministry of Education and Sports (MoES) 1999, 22)? I use the Women's Empowerment Framework (WEF) to argue that the NSGE is deficient both in its identification of challenges to gender-equitable educational opportunities, as well as in the strategies/activities it promotes to address the challenges that it does identify

\section{The NSGE}

The NSGE is '[the Ugandan] Government's call to scrutinise and then harmonise its own and its partners' roles and activities in educating its vital human resource, the girl-child' (MoES 1999, 1). The NSGE opens with a quote from the EFA Conference in Jomtiem in 1990: 'The most urgent priority is guaranteeing access to, and improving the quality of, education for girls and women. This means eliminating all obstacles to their participation' (Article 1, EFA Conference, in MoES 1999, 1).

The NSGE articulates 'the [Ugandan] government's serious commitment to redressing the imbalances and injustices, which have characterised the provision of education for girls in the past' (MoES 1999, Preface). It insists that it is 'the major tool that will guide government, in partnership with all our helpers and stake holders, to 
remove the numerous barriers which prevent our female children from achieving their full potential as equal citizens of their country' (MoES 1999, Preface). The NSGE identifies various barriers to girls' education and outlines programmes and initiatives that are intended to sensitise community and family members about the rights of girls and which promote girls' education, and sets out policies and guidelines for the education of girls that are meant to inform educational practices. The NSGE also acknowledges the importance of the cultivation of girls' self-confidence, autonomy, leadership skills, as well as access to knowledge and information that is relevant and pertinent to their lives. The NSGE appears to extend assessment of achievements pertaining to girls' education beyond merely quantitative ones (i.e. Gross and Net Enrolment Rates), and demonstrates concern with the promotion of gender equity in education in order to develop girls' capabilities and agency so that they can be instrumental in bringing about gender equity in society at large. As such, the NSGE provides a holistic framework in which to consider girls' education. It identifies a wide range of sociocultural, economic, political factors within the family and society, as well as the school environment that hinder the achievement of gender equity in education (and society in general).

The NSGE document is organised as follows:

Introduction

- the introduction articulates the NSGE rationale and overall strategy.

Section I: 'Key Barriers to Equitable Female Participation in Education'

- Section I identifies 18 barriers to girls' education, each of which is subsumed under one of three major categories - 'Socio-cultural Factors', 'School-related Factors' and 'Political/Economic/Administrative Factors'. Key Barriers recognised in Section I are presented as follows:

Socio-cultural Factors

(1) Constraints related to Uganda's patriarchal cultures...

(2) Harmful traditional practices and attitudes which inflict physical and psychological damage, e.g. initiation rituals, early marriage, and bride wealth payment.

(3) Traditional division of labour in the home and school...

(4) Family instability...

(5) Some religious beliefs which reinforce negative cultural practices...

(6) The insecure environment in and outside school, coupled with the girl's physical, social and psychological conditioning to a docile outlook with very low self-esteem...

(7) Differential motivational scope for the male and female child...

School-related Factors

(8) Inadequate school facilities, especially:

(a) sanitation facilities for female students in co-educational institutions;

(b) shortage of secure accommodation for girls in day institutions and the long distances they have to travel, exposing them to constant abuse on the way to school;

(c) lack of provisions in public and private buildings to allow for easy mobility of persons, especially girls, with disabilities.

(9) Lack of comfortable, appropriate clothing.

(10) Negative gender stereotyping in the curriculum, instructional materials, teaching-learning methodology and assessment systems. 
(11) Factors related to school and college personnel

(a) a dearth of attractive, high-profile female role models...;

(b) negative/biased teacher attitudes...;

(c) the absence of trained guidance and counselling personnel...;

(d) a scarcity of personnel trained in gender-screening mechanisms.

(12) Shortage of relevant alternative quality education opportunities and facilities for girls who remain outside school.

(13) A critical bottleneck in female access to secondary and higher education... Political/Economic/Administrative Factors

(14) The general public are largely unsensitised to the importance of girls' education and are ignorant of their responsibility for providing a secure environment for female students.

(15) ...government is yet to allocate sufficient resources ... to respond to the particular needs of girls' education.

(16) Inadequate enforcement of available laws and regulations ... [to] protect the girl child.

(17) Limited availability of and access to gender-disaggregated data...

(18) Poverty constrains the choices available to parents...

Section II (Table A): 'Players Supporting Girls' Education'

- Section II lists 'key players' (e.g. organisations and groups that are involved with addressing certain barriers), the activities with which they are involved, and the coverage of those activities.

- Table A charts 'players', 'activities' and 'coverage' for each of the barriers.

Section III (Table B): 'The Way Forward'

- Section III outlines proposed strategies for each of the identified barriers, or clusters of barriers to achieve the 'Overarching Goal' in which '[a]ll girls in Uganda (including the destitute and girls with disabilities) will have full access to education opportunities and will be supported by their families, schools, communities, government and the private sector to participate fully in genderbalanced education programmes in order to attain their maximum potential as equal and effective citizens' (MoES 1999, 22).

- Table B charts 'objectives', 'strategy/activities', 'collaborating, responsible parties', 'resources available', 'resources needed', 'output/verifiable indicators' and 'target dates'.

Although, in essence, the 18 barriers remain consistent throughout the document, they are frequently articulated slightly differently, and in some cases there are actual discrepancies in substance between sections (e.g. the omission of Barrier $8 \mathrm{~b}$ from Table A), which complicates the overall analysis.

\section{The research context: Kyato Secondary School, Kyato Village}

Kyato Secondary School (KSS) is located in Kyato Village, which borders a trading centre that is approximately seven miles from the nearest urban centre, Ganda Town, in southwestern Uganda (pseudonyms have been used for all participants and locations that might reveal the participants' identities). As in most rural areas of Uganda, poverty is extreme; malnutrition, disease, poor shelter, and high and early morbidity rates (UNICEF 2007) are commonplace. Uganda is also one of the countries that has suffered greatly - socially and economically - from the HIV/AIDS pandemic 
(Jones and Norton 2009; Okware et al. 2005; Muriisa 2006; Schoepf 2003; Serwadda 2003, 29).

Kyato Village is typical of many rural Ugandan communities; it has no electricity, and although piped water became available for a fee in 2004, the vast majority of people cannot afford to access it. Residents are mostly subsistence-level farmers who grow crops such as maize, matooke (green bananas), cassava, sweet potatoes, yams, ('Irish') potatoes, beans, groundnuts, pineapples, mangoes, sweet bananas, jackfruit, papaya, watermelon and guavas for family consumption. Most families possess a small number of livestock (chickens, pigs, or goats) for consumption or to sell in case of financial exigencies (i.e. school fees, medical expenses, etc.). If they own enough land, some families grow cash crops such as coffee and vanilla beans.

There are distinct gender roles: women attend to most of the domestic work and farming; men do some of the farming, but may also earn some income through some labouring opportunities (e.g. making bricks, digging, building houses, driving taxis and boda-bodas, and clearing land) that are not available to women. Women and children, particularly girls, spend hours every day collecting water and firewood, preparing meals, washing clothes and dishes, cleaning the compound, and tending to younger children, as well as the sick and elderly. There are many female-headed households, either because the men are polygamous (and spend time between various homes), the men work elsewhere (e.g. in urban centres), or the women are widowed or divorced (although divorce is not a common practice).

The 15 adolescent girls who participated in this study were class peers at KSS. During the course of the study they transitioned from Senior 3 (S3), the equivalent of Grade 10, to Senior 4 (S4), the equivalent of Grade 11. Because of the small numbers of girls who complete lower (S4) and senior (S6) secondary school, especially in rural contexts, this group of girls provided important insights into this particular demographic. The girls in this study came from families representative of this area. Most of their families survived by subsistence-level farming; a few of the girls' fathers earned small incomes through regular (e.g. tailoring or driving taxis) or irregular (day labour) employment. For some families, the sale of crafts such as mats and baskets made by women and girls, or the sale of extra food grown in the family gardens brought in a small additional income. Each of the girls was responsible for domestic chores and helping with the planting and harvesting of crops. Six of the 15 girls came from primarily female-headed households, nine had polygamous fathers, and each of the girls had been affected personally by HIV/AIDS, for example by the deaths of their siblings, parents, relatives and/or friends.

With the national implementation of Universal Primary Education (UPE) in 1997, primary school was free, however children's secondary school education constituted a serious financial investment for families. The tuition fees at KSS were 150,000 Ugandan shillings (approximately US\$80) a year for day students, and 450,000 Ugandan shillings (approximately US\$250) a year for boarders. Due to the low incomes of their families, the majority of students at KSS missed portions of schooling (ranging in length from several days to several months) as a result of being 'sent home for school fees'.

The school had a mixed population of approximately 200 girls and boys. The school had 13 teachers -11 male (including the headteacher and deputy headteacher) and two female - several of whom were underqualified and all of whom were poorly paid. There were few textbooks, and there was no science lab, no running water, and 
no electricity. KSS did, however, have a close affiliation with the Kyato Community Library (KCL), which was located on the KSS property. Although the two institutions were separately owned and managed, they worked in tandem to serve the KSS student population. For many students, KCL was their only source of books, newspapers, and other educational resources.

\section{Evaluative framework}

In many developing countries, girls' opportunities for education have traditionally hinged on whether it was believed that their education could achieve various objectives, such as healthier families, increased numbers of children receiving vaccinations, improved general nutrition and decreased birth rates (Egbo 2000; Pitamber and Chatterji 2005; Stromquist 1990; Unterhalter 2005a, 2005b, 2006). Consequently, achievement in girls' education has typically been measured relative primarily to numbers of girls in school, or Gross Enrollment Rates (GERs) and Net Enrolment Rates (NERs). Scant attention has been given to the quality of girls' education, girls' specific educational needs, nor ideological considerations to the purpose of education as a means of empowerment for girls (Fiedrich 2004; Longwe 1995). Longwe (1998) argues that schooling that reflects and promotes the gender inequitable norms is 'schooling for subordination'; education for girls is intended to reap benefits for society at large while maintaining the ideological/sociocultural/political status quo. Under these circumstances, with these anticipated outcomes, education is neither meant to empower girls and women to become autonomous agents, nor is it intended to support their personal goals, desires for, and visions of the future.

Recently, however, assumptions of the passive but instrumental benefits of girls' education has been critically examined and 'questions been raised about the purpose of educating women [and girls], challenging the efficiency arguments of the past' (Robinson-Pant 2004, 1). These questions have generated theories of, and approaches to girls' education that reframe its value in terms of its importance in cultivating, for example, empowerment and autonomy, as well as providing skills and knowledge that enable girls and women to have the freedom and support they need to realise their personal aspirations and well-being (Nussbaum 2003a, 2003b; Robeyns 2006; Saito 2003; Sen 1999; Subrahmanian 2005; Unterhalter 2005a, 2005b). The NSGE states a commitment to provide girls with such empowering educational opportunities, and this paper will assess the extent to which it has been successful, based on the experiences of the 15 girls, as well as the reflections of the teachers and school staff who participated in this research.

I draw upon the Women's Empowerment Framework (WEF) to evaluate aspects of the NSGE pertinent to this study. The WEF is based on the Longwe Framework for Gender Analysis, developed by Zambian feminist, political activist and consultant on gender and development, Sara Longwe, ${ }^{1}$ which has been adapted as a framework of analysis for education by Fiona Leach (2003b). Longwe (1998) argues that programmes and policies concerning gender equity need to be evaluated in terms of how they address a hierarchical matrix of empowerment that examines their commitment to the active and genuine goal of empowerment. She maintains that empowerment 'entails women increasing their level of control over the allocation of resources by identifying and ending the discriminatory practices which stand in their way' (Longwe 1998, 23). The importance of the WEF is its intention 'to help policy makers, planner, managers, and evaluators assess the extent to which a policy, orga- 
nization, or programme is committed to women's empowerment, and if so, to what kind of empowerment and with what impact' (Leach 2003b, 56).

The WEF identifies five levels, arranged in hierarchical order, of equality; empowerment is assessed by the extent to which each of these levels exists in social or economic situations or programming. Following is an outline of the levels articulated in the WEF, ranging from lowest to highest:

(1) Welfare

- This measures women's material welfare in relationship to that of men. Leach (2003b) suggests that in the area of education, welfare could refer to incentives that enable girls to attend school (e.g. free uniforms, no school fees, etc.).

(2) Access

- This level is concerned with equal opportunities for girls to attend school.

(3) Conscientisation

- 'This is the conscious understanding of the difference between sex and gender, and an awareness that gender roles, including the sexual division of labour, are culturally determined and can be changed' (Leach 2003b, 58). Within education, conscientisation can be assessed as the extent to which students and teachers problematise assumptions around sex and gender and actively work towards gender-equitable relationships.

(4) Participation

- Within the school environment, participation refers to decision-making, leadership roles, involvement in extra-curricular activities, and having a

(5) Control voice (that is welcomed and listened to) in all areas of learning.

- This is the highest level and is concerned with balance of power between women and men, girls and boys.

The WEF is a powerful lens through which data collected in this study can be analysed in relation to the NSGE, as the clearly defined and hierarchical nature of the levels outlined above afford effective guidelines within which to evaluate the degree to which the NSGE has been successful at supporting the empowerment of girls. In this article I focus on six issues that my data reveal to be particularly severe, fundamental and pervasive challenges related to education as experienced by the girls in this study: school location; menstruation; pedagogical practices and attitudes; sexual exploitation and abuse within the school environment; lack of income-earning opportunities; and domestic responsibilities. I explore if/how the NSGE addresses these challenges, using the WEF framework to evaluate the effectiveness of the NSGE's interventions.

\section{Methodology}

This is a longitudinal case study that uses mixed methods to consider multiple facets of the participants' lives as well as the complexities of the research context. I explore power relations, traditional gender roles, socioeconomic challenges and opportunities, as well as available human and material resources in order to render a complex representation, or 'thick description' (Geertz 1973, 3-30), of the girls' lives and experiences. This concurs with Vavrus' description of ethnographic policy research that places 'emphasis on relations of power, on cultural practices that affect 
policy interpretations, and on sustained engagement with residents in a local setting' (2005, 175).

The fieldwork for this study took place from August 2004 to August 2005, during which time I worked closely, in a number of capacities with KSS and the Kyato community. I attempted to provide and participate in as many varied contexts as possible in which to interact with the girls. I explored the dynamics of the school environment, such as teacher-student interactions, female-male student interactions, pedagogical approaches, and extra-curricular activities. I also journeyed with the girls beyond the classroom and the school ground to observe other angles of their lives. Data collection methods with the girls included videotaped interviews, questionnaires, focus group discussions, and multimodal inquiry (including photography, drama, art, writing and music). Data were also collected from teachers at KSS through interviews and questionnaires, as well as from questionnaires completed by teachers at two primary schools in Kyato Village. In addition, data were collected from other students at KSS from questionnaires and focus group discussions. Other data included observation, journaling, ${ }^{2}$ and document analysis.

My study used constructivist grounded theory (Charmaz 2006, 2008) to explore issues of importance that emerged from my research. Interviews, questionnaires and focus group discussions triangulated findings as well as provoked new dimensions of data collection and analysis. This process was particularly useful in acquiring multiple perspectives and exploring conflicting attitudes between female students and teachers, as well as deepening my inquiry into senstive issues around sexuality and the nature and range of relationships with which the girls were involved. This paper is primarily concerned with data from the girls taken from interviews conducted at the outset and conclusion of my fieldwork, questionnaires completed during my fieldwork (May 2005) and a follow-up questionnaire completed in September 2006, and several focus group discussions conducted during my fieldwork. Other data referred to in this paper include interviews with teachers at KSS and questionnaires completed by the teachers at KSS as well as teachers at two local primary schools (30 teachers in all).

I integrated myself into the community by teaching English to the Senior 3 (or S3, the equivalent to Grade 10) class at KSS, and co-facilitating a weekly lunch-hour sexual health club, the Straight Talk Club, based on a nationally distributed sexual health newsletter, Straight Talk, designed for youth. In addition, I visited women's and other community groups, taught a women's literacy class at the community library, and visited the local primary schools, health clinics and other institutions, working closely with research assistant and translator, Daniel Ahimbisibwe.

\section{Findings and discussion}

My study found that all 18 barriers to girls' education identified in the NSGE were indeed present in the context in which my research was conducted. However, as discussed above, I have limited the discussion in this paper to six particularly salient challenges - school location, menstruation, pedagogical practices and attitudes, sexual abuse and exploitation within the school environment, lack of income-earning possibilities, and domestic responsibilities - that emerged from my data. In this section I will discuss each of those challenges in relationship to the NSGE, and consider to what extent interventions have impacted girls' education within the evaluative framework of the WEF. I will lead with data from the respondents, followed by 
a consideration of the extent to which and how the NSGE addresses these challenges, which I will then evaluate within the WEF.

\subsection{School location}

\subsubsection{Findings from data}

The distance from home to school was problematic for several of the girls in this study. The girls at KSS had a daily walking commute of up to 16 miles, often along desolate stretches of roads and paths, which took up to five hours a day. This posed to be problematic for three reasons. First, girls, particularly adolescent girls, were regularly harassed and sexually assaulted when walking alone (Geiger 2002). Out of 11 teachers and staff (two female, nine male) at KSS who completed questionnaires (June 2005), 10 teachers (one female, nine male) identified long distances to school as problematic for girls, and seven of those teachers (one female, six male) believed that 'vulnerability to harassment' due to long distances to school was a serious impediment to girls' equal access to education. During an interview (August 2005), Juliet conveyed her experiences commuting to school:

Shelley: What is the biggest problem or difficulty that you have in your life right now?

Juliet: $\quad$ The biggest problem - is these men who disturb us - begging for sex.

Shelley: When you are walking to school?

Juliet: Yes...

Second, girls were expected to assume a larger share of domestic chores than were boys, and long commutes intensified the pressure for girls to complete domestic chores before and after school, sometimes at the expense of their attendance at school, or available time for homework (this will be further discussed in Section 6.6.2). Third, in some Ugandan cultures, such as the Buganda, to which these girls belonged, girls were not permitted to ride bicycles (Parry 2004; Pitamber and Chatterji 2005), so their commuting time was consequently far greater than that of boys with bicycles.

\subsubsection{Relationship to NSGE}

Section I of the NSGE addresses the issue of school location in Barrier 8, subsection 'b': 'shortage of secure accommodation for girls in day institutions and the long distances they have to travel, exposing them to constant abuse on the way to school'. However, Barrier $8 \mathrm{~b}$ is conspicuously absent in Table A, suggesting there are no measures in place to mitigate this challenge (Table 1.1).

In Section III (The Way Forward) Barrier $8 b$ ('shortage of secure accommodation for girls in day institutions and the long distances they have to travel, exposing them to constant abuse on the way to school') is reintroduced, and peripherally addressed in Objective 2: 'Expand and segregate sanitation and accommodation facilities to cater for increased enrolment [of girls] especially at primary level'. However, the only strategy that addresses this barrier is included within one subset of 'strategies/ activities' that states: 'Construct hostels for girls within day school vicinities in each district' (Table 1.2).

Thus, the only activities that even incidentally address the very significant issue of school location is the construction of hostels. 
Table 1.1. NSGE Barrier 8 (Table A, Section II - Players Supporting Girls' Education).

\begin{tabular}{|c|c|c|}
\hline Player & Activity & $\begin{array}{l}\text { Coverage (area, } \\
\text { population, funding) }\end{array}$ \\
\hline
\end{tabular}

Barrier 8. Inadequate school facilities, especially:

(a) sanitation

(b) accommodation for girls in day institutions*

(c) lack of provisions in buildings allowing easy mobility of disabled persons, especially girls

YMCA

Irish Aid

Action Aid

ANDRA with

DANIDA

Offer hostel facilities at Headquarters and encourage members in other districts to construct similar hostels

10 districts. No. of hostels?

Support education generally in classroom

Kibaale District construction...

Work with communities to construct classrooms (not exclusive to girls)

5 districts

School construction...

465,578 primary school children of whom 256,618 are girls

? districts

Church/Uganda Province

Constructed hostel for disadvantaged upcountry girls studying in Kampala

1 hostel for? girls

CAP (supported by Royal Netherlands Government)

WFP

Support construction of dormitories, sick bay, West Nile latrines/bathrooms, and science lab for secondary schools

Through Food for Work activities supported West Nile construction of 20 school buildings and latrines

Catholic Church A school for children with parents with AIDS N/A

Note: See Table 7 for a list of acronyms and abbreviations.

* $8 \mathrm{~b}$ here differs from $8 \mathrm{~b}$ as expressed in Section I of the NSGE: 'shortage of secure accommodation for girls in day institutions and the long distances they have to travel, exposing them to constant abuse on the way to school'.

\subsubsection{Considered within the WEF}

In terms of school location, the NSGE does not transcend the level of conscientisation within the WEF. It acknowledges that location has gendered dimensions and negatively impacts girls' educational opportunities, but it does not propose any specific interventions that would enable girls to participate in creating solutions to overcome the challenges associated with location. My study indicates that there are a wide variety of approaches that could be taken to overcome many problems associated with location and long commutes - school buses, walking escorts, established walking groups, commuting 'checkpoints', allowing girls to ride bicycles (even bicycles for two riders), flexible school schedules - that would greatly increase girls' general accessibility to, and regular attendance at school.

\subsection{Menstruation}

\subsubsection{Findings from data}

A questionnaire (May 2005) completed by 13 of the girls in this study indicated that 12 considered menstruation to be a problem. All 13 of the girls had missed school due 


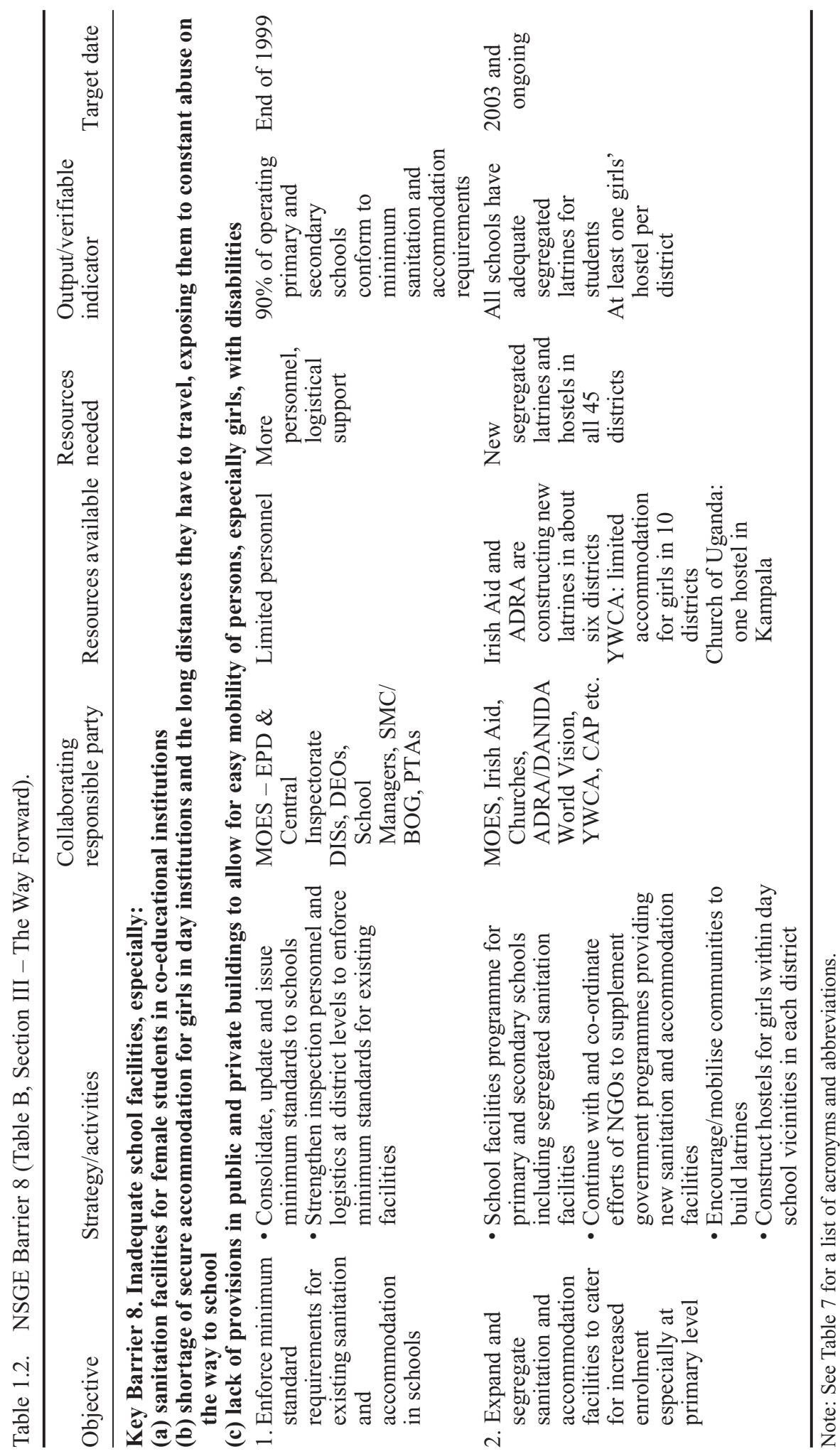


to menstruation, some up to five days a month. Some girls had missed school due to physical pain and discomfort, but most had missed school because of the problems associated with menstrual bleeding and lack of access to sanitary napkins and water for washing.

During the second Straight Talk Club meeting with the girls [they asked me] what they could do about the problem of blood running down their legs and spoiling their clothes, during menses ... The humiliation of blood-spattered legs or blood-soaked clothing, and the lack of discreet washing areas was enough to keep many girls away from school during their periods, especially as there was no running water, and in order to get water to wash, they had to walk about a kilometre. In addition, many suffered from severe menstrual cramps, and were unable to afford any aspirin or other medication to alleviate the pain. (Excerpt from fieldnotes, October 2004)

Provision of sanitary materials is necessary if girls are to have equitable educational opportunities.

\subsubsection{Relationship to NSGE}

Surprisingly, issues and challenges concerning menstruation are not mentioned at all in the NSGE. The one article of the NSGE that could address the provision of sanitary materials and other material support is Barrier 9 (see Table 2.1). However, little more than passing mention and obscure reference is given to this very important issue. Table A in Section II indicates that there are no 'players', no 'activities' and no 'coverage' at all for Barrier 9.

In Table B, Section III, Barrier 9 is given some consideration, although the issue of menstruation is not addressed with any more than a vague suggestion that schools provide, and/or that school personnel are 'sensitive' to the need for comfortable clothing, including sanitary wear, for girls (Table 2.2). Certainly, the girls at KSS received no support whatsoever from the school for challenges linked to menses.

\subsubsection{Considered within the WEF}

The lack of focused attention given to menstruation is a serious shortcoming in the NSGE, given that many girls miss up to $25 \%$ of their schooling due to problems associated with menstruation. Thus, with respect to this challenge, the NSGE does not even reach the welfare level of the WEF.

\subsection{Pedagogical practices and attitudes}

\subsubsection{Findings from data}

Teacher-centered, authoritarian pedagogical approaches typical in Ugandan classrooms reinforce cultural gender inequalities with respect to power because they situate

Table 2.1. NSGE Barrier 9 (Table A, Section II - Players Supporting Girls' Education).

\begin{tabular}{lll}
\hline Player & Activity & Coverage (area, population, funding) \\
\hline $\begin{array}{l}\text { Barrier 9. Lack of appropriate, comfortable school clothing allowing girls free active } \\
\text { participation }\end{array}$ & N/A & N/A \\
N/A & N
\end{tabular}




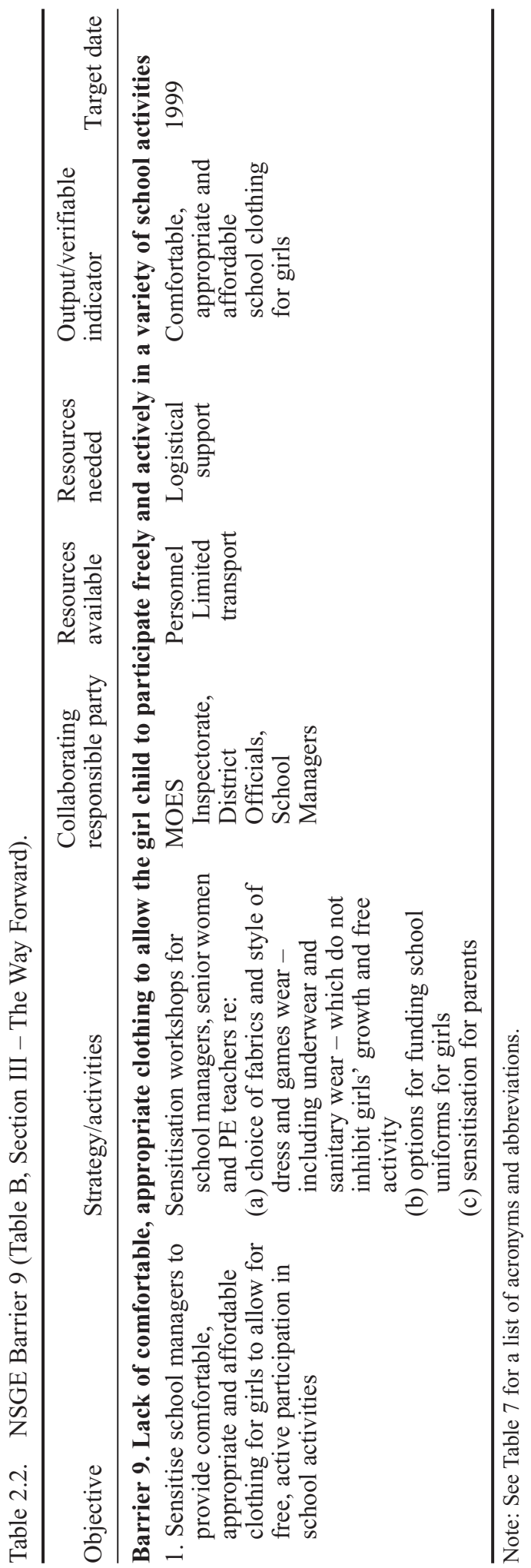


the teacher (usually male) at the centre of the classroom environment in a position of control, demanding acquiescent and compliant behaviour from the students, especially girls (Ansell 2002; Kakuru 2006; Mirembe and Davies 2001). In addition, teachers' attitudes and assumptions about girls' capabilities and degrees of motivation strongly impact girls' educational opportunities (Geiger 2002; Mirembe and Davies 2001; Sperandio 2000). Results from a questionnaire (June 2005) shows that almost half the teachers (seven out of 15) at KSS believed that boys were treated as intellectually superior to girls. Representative responses are as follows:

- 'Boys are considered to be with a high reasoning capacity'. (male teacher)

- 'Girls lack the stamina to stick to their goals'. (male teacher)

- 'Girls less value education'. (male teacher)

This study found that many teachers did not believe girls to be as ambitious, or as 'serious', about education and future careers as boys. Of the 15 (three female and 12 male) teachers and staff at KSS who completed the questionnaire (June 2005) eight teachers (one female and seven males), just over half, believed that girls were less ambitious than boys. Other teachers, however, believed that girls were equally as ambitious as boys, but that cultural practices and beliefs inhibited girls from outwardly displaying their ambition, leading people to believe that girls did not possess the same drive to succeed as did boys. In an interview, the Headteacher, Mr. Masinde commented: 'in the cultural training, the girls are trained always to - not to come up very much'.

\subsubsection{Relationship to NSGE}

6.3.2.1. NSGE barrier. To some extent, the NSGE does acknowledge the problems associated with teachers' lack of support for girls' educational and professional aspirations, such as referred to in Barriers 7, 10 and 11 (see Tables 3.1 and 3.2). However, little was in place to address this issue (see Table 2.1) directly. I have italicized those activities that respond to the problem of negative pedagogical practices and attitudes (Table 3.1).

As indicated in Table 3.1, Barriers 7, 10 and 11 demonstrate an awareness of the pressing need to reform the general educational experience for girls, involving curricular materials, the school environment, teachers' attitudes and even community awareness of human rights issues.

Table B, Section III gives attention to this issue within the Key Barriers 1-7 Section, Objective 2, as outlined in Table 3.2. (Because Barriers 1-7 are grouped together in Table B, and constitute a lengthy chart, I have focused here only on the relevant Objectives and Strategies pertaining to the issue of pedagogical attitudes and practices.)

However, there is nothing within Barriers 10 or 11 that address the problems of negative pedagogical attitudes and practices, suggesting that this is not a priority for future planning and initiatives.

\subsubsection{Considered within the WEF}

The overall approach to the issue of negative pedagogical attitudes and practices of the NSGE as outlined in Tables 2.1 and 2.2 seems to be to 'sensitise' others and 


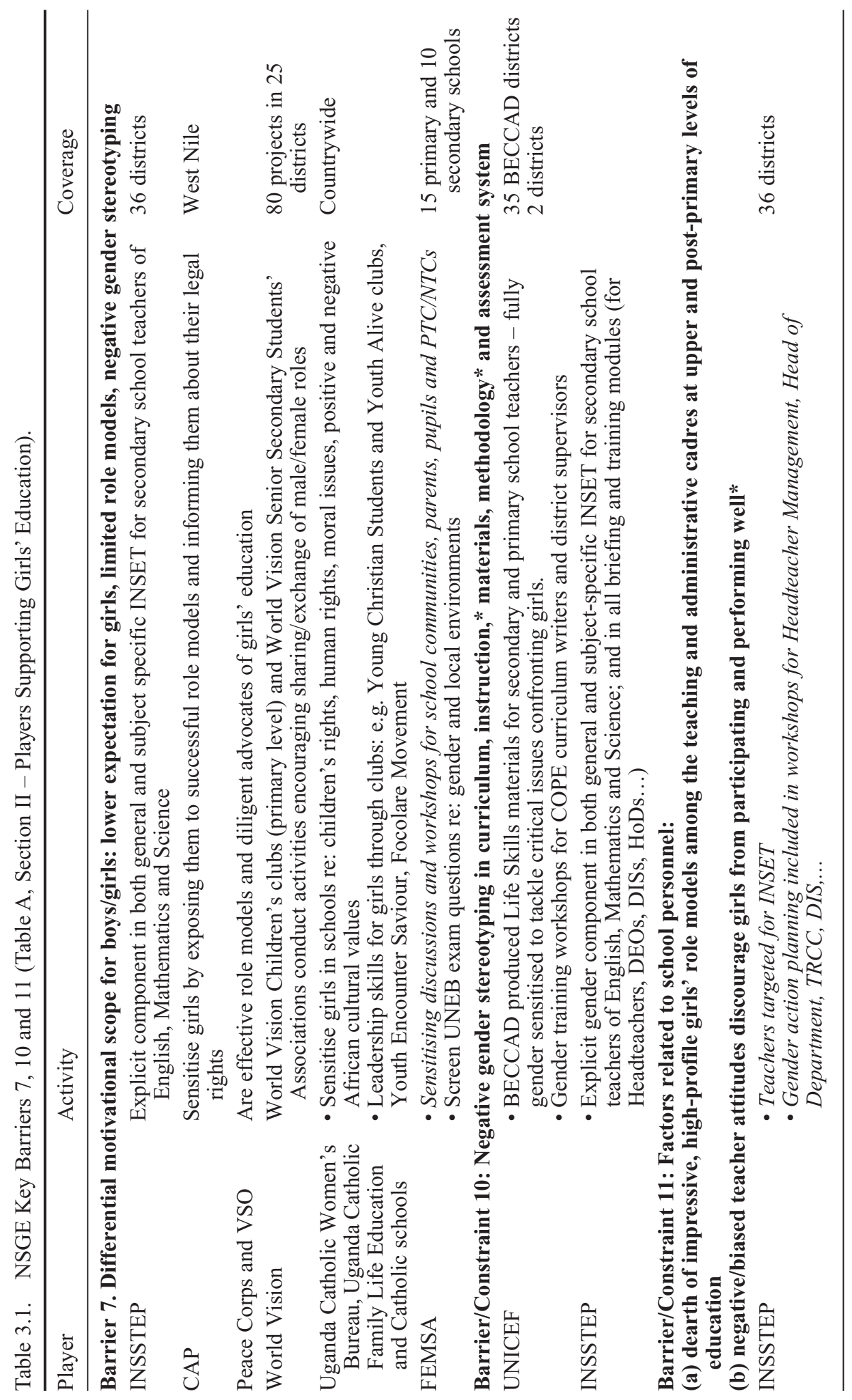




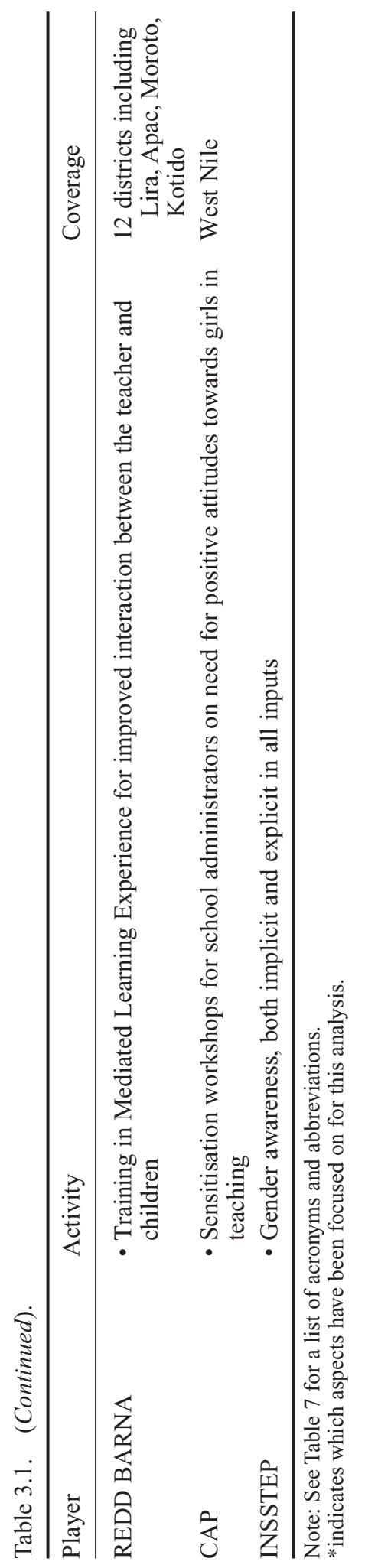




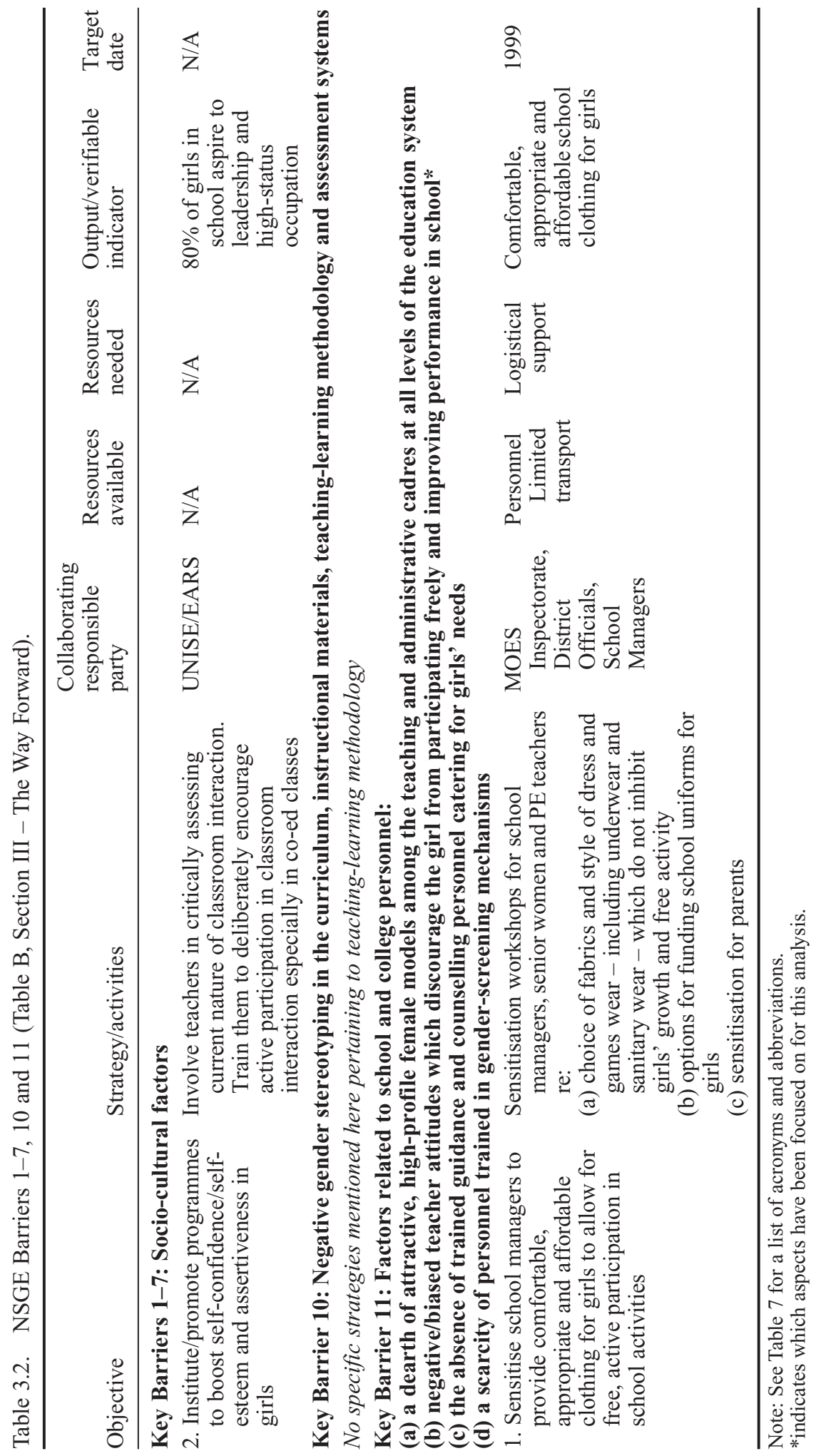


provide girls with positive role models, but not to actively engage girls in processes that would work towards dispelling negative assumptions about girls abilities and ambitions. In terms of the WEF, the NSGE has achieved the level of conscientisation, but has not reached higher levels, as there is little emphasis on actual provisions to support the full participation of girls, or to provide them with control over the situation.

\subsection{Sexual exploitation and abuse within the school environment}

\subsubsection{Findings from data}

Findings from my study concur with others that reveal sexual exploitation and abuse to be very serious and prevalent problems for girls at school (Edinburgh Global Partnerships n.d.; Lacey 2003; Luke 2003; Ndyanabangi et al. 2001; Mirembe 2004; Mirembe and Davies 2001; Nyanzi, Pool, and Kinsman 2001; Okee-Obong 2000; Scheier 2006; Sperandio 2000; Twa-Twa 1997). In a questionnaire completed by 13 girls (May 2005), all 13 of the girls stated that they knew of girls who had had sex with their teachers. Out of the 12 girls who completed a follow-up questionnaire (September 2006), three said that they had had sex with secondary school teachers, two for money and clothes and one out of fear. Three girls, two of whom had sex with teachers, stated that they were 'afraid to refuse a request for sex' from teachers because they feared violent repercussions as a result of their refusal.

Penina: We young girls, we are forced to have sex with other mens - like the teachers...

Shelley: So - do you know girls that have had to have sex with teachers?

All girls: Yes.

Shakila: Even in our school... (Excerpt from focus group discussion, January 2005)

In questionnaires administered to teachers at KSS (November 2004) as well as the two primary schools in Kyato Village (July 2005), of the 30 teachers who responded, 17 indicated that they knew of teachers who had had sexual relationships with their students, and 20 out of 30 teachers believed this to be a general problem in Uganda.

In addition to sexual abuse/misconduct by teachers, girls suffered sexual abuse and harassment from boys their own age. Half of the girls (six out of 12) who completed the September 2006 questionnaire stated that they had been 'afraid to refuse a request for sex' from a boy their own age. It seems that these inequalities were exacerbated within the confined space of the school, particularly at boarding schools where boys and girls were living in very close quarters and are not supervised effectively at all times. Several of the girls expressed their desire to attend girls-only schools because, as Sofia stated in an interview (August, 2005): 'girls are mistreated' by boys, and boys 'end up making them pregnant'.

\subsubsection{Relationship to NSGE}

The problem of the sexual violation of girls within the school environment is alarmingly absent within the NSGE; it is not even recognised, let alone focused on, despite its prevalence and the commonplace knowledge of it. Although the NSGE addresses the general problem of the sexual abuse of girls by Barriers 6 - '[i]nsecure environment in and outside school' - and 16 - '[i]nadequate enforcement of available 
Table 4.1. NSGE Barriers 6 and 16 (Table A, Section II - Players Supporting Girls' Education).

\begin{tabular}{lll}
\hline Player & Activity & Coverage \\
\hline $\begin{array}{ll}\text { Barrier 6. Insecure environment in and outside school } \\
\text { FIDA }\end{array}$ & $\begin{array}{l}\text { Baseline study on defilement in school-going } \\
\text { girl children. Produced information leaflets on } \\
\text { defilement for girls } \\
\text { - Have finalised study on Child Mothers, } \\
\text { focusing on girls getting pregnant in school. } \\
\text { Research to be used to advocate for policy on } \\
\text { continuing education for such girls }\end{array}$ & $\begin{array}{c}\text { Mukono, } \\
\text { Kampala, } \\
\text { Masaka }\end{array}$ \\
$\begin{array}{lll}\text { INSSTEP (Networking } \\
\text { with Uganda Police } \\
\text { Gender Desk) }\end{array}$ & $\begin{array}{l}\text { Component of INSET on Child Protection and } \\
\text { creating a secure environment in schools for } \\
\text { (a) secondary school teachers of English, }\end{array}$ & N/A \\
$\begin{array}{lll}\text { Barrier/Constraint 16: Inadequate enforcement of available laws to protect person and } \\
\text { interests of the girl child } \\
\text { N/A }\end{array}$ & N/A & N/A \\
\hline
\end{tabular}

Note: See Table 7 for a list of acronyms and abbreviations.

laws to protect person and interests of the girl child' (Tables 4.1 and 4.2), it does not adequately target the specific problem of sexual harassment, exploitation and abuse within the school environment, by both male teachers and students, other than by stating the need for child protection committees at schools and codes of conduct for teachers (see Table 4.2). In terms of existing measures, Section II, Table A states that a study on defilement has been conducted by FIDA (the Federation of Women Lawyers) in four districts. Table A also indicates that there has been some in-service teacher education on the topic by INSSTEP (In-Service Secondary Teacher Education Project), but the coverage is unknown (or at least not stated); teachers at KSS had not received any interventions on this issue (Table 4.1).

Table B, in Section III, indicates a number of strategies to be implemented within the school and community environment, ranging from community awareness of human rights, to enforcement of existing laws to the creation of child protection committees at every school, to codes of conduct for teachers, although many of these strategies have no resources available and have no target dates set (Table 4.2). None of these measures were in place in the context of KSS.

There are two strategies stated within Objective 1 that do have target dates 'Empower girls with life skills and expose all pupils and community to legal and human rights especially re: sexual harassment/defilement' (1998) and 'Enforce senior woman teacher post and established child protection committee in every school to deal with sexual harassment' (2003) - but there was no evidence of either of these within the context of KSS.

\subsubsection{Considered within the WEF}

In terms of the WEF, the NSGE has achieved the level of conscientisation around the issue of sexual exploitation and abuse, but the existing and proposed strategies lack focused attention to this issue as it exists within the school environment. Possibly, the proposed strategy to 'empower girls with life skills' could be considered a weak 


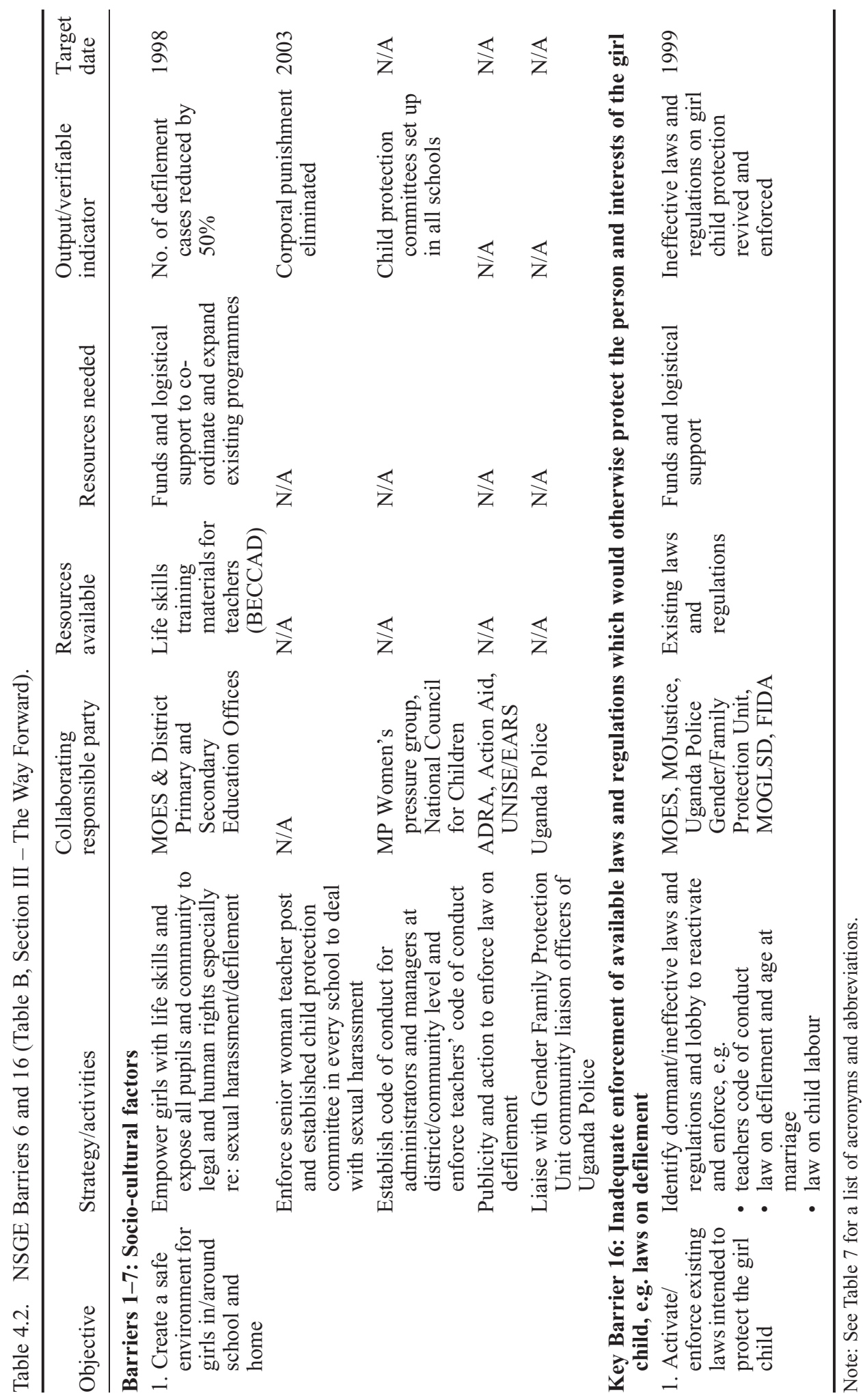


example of participation within the WEF, but there is little emphasis on actual provisions (e.g. free and easily accessible legal counsel, grievance procedures, etc.) that support girls with viable choices for security, and/or courses of action to take if they are harassed, abused or assaulted.

\subsection{Lack of income-earning opportunities}

\subsubsection{Findings from data}

Beyond primary school, where there were expenses related to tuition, exams, field trips, boarding, and school supplies, girls were at a distinct disadvantage. Boys were able to earn money from seasonal and part-time employment, whereas girls had no such opportunities (Freedman and Poku 2005; Kweisga 2002; Nyanzi, Pool, and Kinsman 2001; Pitamber and Chatterji 2005). This led many girls into transactional sex (sex for money) as a way to finance their education. In a questionnaire given to 13 of the girls in May 2005, 12 of the girls noted that it was common for girls to have sex in order to raise money for school fees. In a questionnaire given to the girls in September 2006, of the 10 girls who stated they were sexually active, nine relayed that they had received gifts or money for sex. One girl said, 'I used that money to buy things that helped me to stay at school'. Another commented, 'some parents failed to pay school fees for girls and then she decide to exchange sex in order to get money'. Another significant finding is that it was not unusual for parents to encourage girls to earn money through sex. In answer to the question (May 2005 questionnaire), 'Do you know of any parents who have encouraged girls to have sex in order to pay school fees?', 12 of 13 girls answered in the affirmative. One girl, Shakila, talked about her own experience during a focus group interview in January 2005:

Our mother can force us to, to go and practise fornication. If you say at home, 'Mum, I want books, pencils. I don't have a uniform', she can tell you that 'I don't have money.

What can you do? You can go and practise fornication in order to get money'.

\subsubsection{Relationship to NSGE}

The NSGE makes no mention of the lack of income-earning opportunities for girls even though lack of money for school-related expenses is the main reason most girls do not attend school, especially at the post-primary level.

\subsubsection{Considered within the WEF}

The NSGE does not even reach the level of welfare for this issue.

\subsection{Domestic responsibilities}

\subsubsection{Findings from data}

Given the gendered nature of domestic work, it was often considered to be an 'opportunity cost' to have girls attend school rather than help with farming, care of younger children and general household duties. Also, in family emergencies, girls were expected to take over the running of the home. During the period of my research one girl, Gelly, was forced to miss over a month of school because her father had to spend a prolonged period in the hospital and Gelly's mother was obligated to stay with him 
to serve him meals, do his laundry, and perform other duties, as the public hospitals cannot provide these services. Gelly, therefore, had to attend to all of the household duties, including looking after young family members.

\subsubsection{Relationship to NSGE}

The NSGE identifies the problem of unequal domestic burdens in Barriers 1 and 3 (see Tables 5.1 and 5.2). However, nothing was in place to address this issue (see Table 2.1) directly.

Table B, Section III, gives attention to this issue within the Key Barriers 1-7 Section, Objective 2, as outlined in Table 5.2 (Because Barriers 1-7 are grouped together in Table B, and constitute a lengthy chart, I have focused here only on the relevant Objectives and Strategies pertaining to the issue of domestic labour.)

However, as indicated in Table 5.2 there are no collaborating/responsible parties, no available (or requested) resources and only a vague output/verifiable indicator to address the very serious challenge of the unequal burden of domestic responsibilities for girls.

Table 5.1. NSGE Barriers 1 and 3 (Table A, Section II - Players Supporting Girls' Education).

\begin{tabular}{|c|c|c|}
\hline Player & Activity & Coverage \\
\hline \multicolumn{3}{|c|}{$\begin{array}{l}\text { Barrier 1. Patriarchal cultures - boys' interests/welfare paramount and girls' education } \\
=\text { opportunity cost }\end{array}$} \\
\hline UNICEF & $\begin{array}{l}\text { - Support for accelerated female enrolment in } \\
\text { formal and non-formal (COPE) education } \\
\text { - The Sara Initiative: video, serialisation in print } \\
\text { media, festival education campaign }\end{array}$ & $\begin{array}{l}35 \text { districts (through } \\
\text { BECCAD); } 7 \text { districts } \\
\text { (COPE), PTAs, } \\
\text { Headteachers, senior } \\
\text { women teachers, district } \\
\text { education staff }\end{array}$ \\
\hline USAID & $\begin{array}{l}\text { - Incentive grants/Promotion of Girls Education } \\
\text { (PGE) Scheme to support persistence and } \\
\text { performance of girls in primary education } \\
\text { - TDMS community mobilisation programme has } \\
\text { components targeting girls education } \\
\text { - TDMS outreach programme through core PTCs } \\
\text { train, supervises and monitors teachers to give } \\
\text { girls' needs proper attention }\end{array}$ & $\begin{array}{l}580 \text { schools in } 10 \text { districts and } \\
400 \text { schools in } 5 \text { districts } \\
\text { awarded grants }=\text { sh } 1.2 \\
\text { billion } \\
\text { Future coverage } 45 \text { districts? }\end{array}$ \\
\hline \multicolumn{3}{|c|}{ Barrier 3. Traditional division of labour at home and school } \\
\hline GTZ & $\begin{array}{l}\text { Support to urban out-of-school children; special } \\
\text { emphasis on girls through non-formal basic } \\
\text { education approaches }\end{array}$ & $\begin{array}{l}\text { Kampala district, ? other } \\
\text { urban centres }\end{array}$ \\
\hline WETSU & $\begin{array}{l}\text { Women's science award to best female science } \\
\text { student at } P \& \text {, 'O' and 'A' levels }\end{array}$ & $\begin{array}{l}\text { Targets } 8 \text { sub-regions. } 1 \text { award } \\
\text { so far. Funds sought. }\end{array}$ \\
\hline ADRA & $\begin{array}{l}\text { (AUTEP) Inservice teacher and Management } \\
\text { training gives teachers competence to handle } \\
\text { girls' issues }\end{array}$ & $\begin{array}{l}\text { Trained } 112 \text { teachers and } 150 \\
\text { female school managers; } \\
\text { reached } 8525 \text { girls }\end{array}$ \\
\hline UMS & $\begin{array}{l}\text { National mathematics contests which equitably } \\
\text { reward girls and boys excelling in mathematics }\end{array}$ & $\begin{array}{l}\text { Primary and secondary } \\
\text { schools nationwide }\end{array}$ \\
\hline
\end{tabular}

Note: See Table 7 for a list of acronyms and abbreviations. 
Gender and Education $\quad 407$

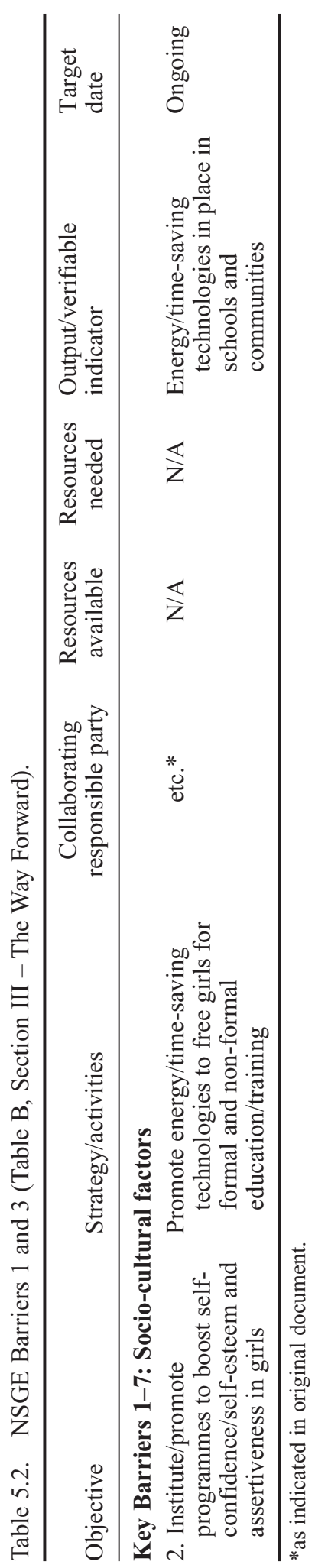




\subsubsection{Consideration within the WEF}

Thus, this issue remains at a level of minimal conscientisation in the WEF framework.

\section{Conclusion}

Longwe's WEF constitutes an enormously valuable tool with which to evaluate the relationship between the NSGE and this study's participants' educational experiences. Table 6 represents my assessment of the NSGE, evaluated through the lens of the WEF, with respect to the ways in which it addresses the six key challenges - school location, menstruation, pedagogical practices and attitudes, sexual exploitation and abuse within the school environment, lack of income-earning opportunities and domestic responsibilities - identified by the participants in this study. For each of these I indicate if they have been identified within any of the NSGE Barriers, and then consider what level of the WEF they reach in terms of the strategies/activities meant to address them. The welfare column considers whether the particular challenge is addressed at all; the access column reflects whether/how girls' access to school/equal learning opportunities is addressed; the conscientisation column considers whether the NSGE has sufficiently problematised the challenge in order to propose effective approaches to overcoming the challenges; the participation column evaluates the degree to which the NSGE promotes girls' participation in the strategies to overcome the challenges; and the control column indicates whether the NSGE articulates ways in which it is committed to supporting girls to the point that they can take control over situations that create the challenges they face.

Reflecting upon my research question I conclude that the NSGE has not made much progress towards achieving its goal of 'remov[ing] the numerous barriers which prevent our female children from achieving their full potential as equal citizens of their country'. Considered within the WEF, the NSGE offers essentially no genuinely empowering interventions for the six challenges considered in this paper. Instead, the NSGE seems primarily concerned with the identification of 'barriers' to girls' education (some of which have been either overlooked or deliberately excluded), and the indexing of parties and programmes that have been or will be involved in addressing various aspects of these barriers.

The NSGE appears to have cobbled together inventories of existing resources with lists of widely acknowledged challenges to girls' education and mapped them into a single document, which links any party and/or programme from the general inventory to any of the aspects of the challenges identified within the 18 barriers of the NSGE. As Seel and Gibbard argue, the NSGE 'seems more an advocacy rather than a strategic document' $(2000,29)$. The NSGE has value as a document that inventories and links a wide range of stakeholders and issues, but it does not propose any radically innovative insights or course of action that would drastically increase gender equity in education. Although there is enormous potential for the serious advancement of girls' education through measures such as the NSGE, there are many shortcomings, including a lack of co-ordination on the part of all the parties supporting and implementing these initiatives, insufficient geographical coverage, deficiencies in monitoring, evaluation and enforcement, and the dependency on donors for many of the initiatives (and, therefore, lack of sustainability).

In addition, the NSGE does not seem to have the political backing necessary to ensure that girls' barriers to education receive serious and urgent attention at all levels of educational programming, planning and policy-making. In fact, the NSGE has not 


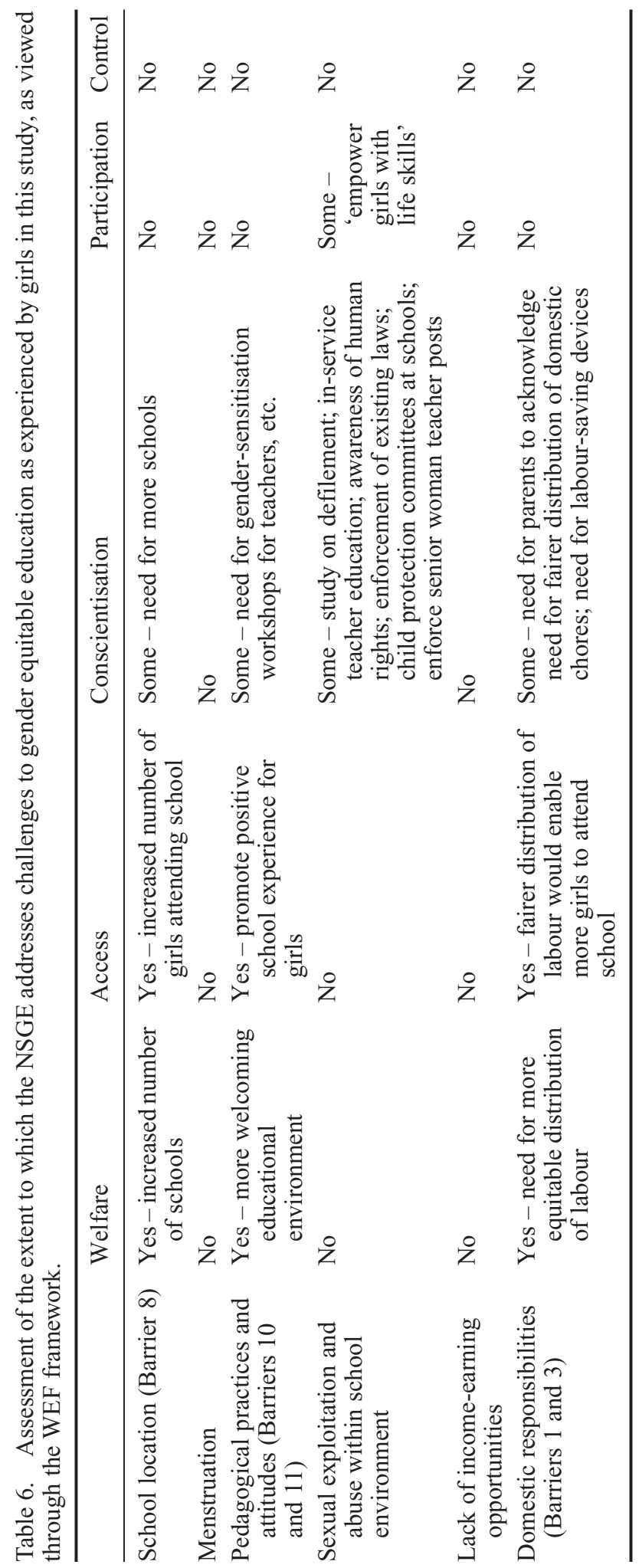


Table 7. List of acronyms and abbreviations in excerpts from the NSGE document.

\begin{tabular}{ll}
\hline ADRA & Adventist Development and Relief Agency \\
BECCAD & $\begin{array}{l}\text { Basic Education, Child Care and Protection and Adolescent } \\
\text { Development } \\
\text { Community Action Programme - West Nile }\end{array}$ \\
CAP & Complementary Opportunity for Primary Education Programme \\
DANIDA & Danish International Development Agency \\
DEO & District Education Officer \\
DIS & District Inspector of Schools \\
EARS & Educational Assessment and Resource Services \\
EPD & Educational Planning Department (MOES) \\
FEMSA & Female Educationalists in Mathematics and Science in Africa \\
FIDA & Federecion International De Abogada / Federation of Women Lawyers \\
GTZ & German Technical Cooperation \\
HoD & Head of Department \\
INSET & In-Service Teacher Education \\
INSSTEP & In-Service Secondary Teacher Education Project \\
MOES & Ministry of Education and Sports \\
MOGLSD & Ministry of Gender, Labour and Social Development \\
MoJustice & Ministry of Justice \\
NTC & National Teachers' College \\
PTA & Parents Teachers Association \\
PTC & Primary Teachers' College \\
REDD BARNA & Norwegian Save the Children \\
SMC & School Management Committee \\
TDMS & Teacher Development and Management System \\
UMS & Uganda Mathematics Society \\
UNEB & Uganda National Examinations Board \\
UNICEF & United Nations Children's Fund \\
UNISE & Uganda National Institute of Special Education \\
USAID & United States Agency for International Development \\
VSO & Voluntary Service Overseas \\
YWCA & Young Women's Christian Association \\
\hline &
\end{tabular}

been incorporated into the GOU's Education Sector Investment Programme (ESIP), a policy document under the general Sector Wide Approach Programme (SWAP), that is used to plan, co-ordinate, and implement all education programming, as well as allocate resources from national and international sources. Thus, the NSGE has been sidelined from mainstream educational priorities.

Young women, such as the participants in this study, have immense potential to bring about fundamental and sweeping transformations leading to the realisation of gender equity, social justice and improved quality of life within their society. However, young women require supportive family, community and institutional structures, and policy and programming that have effective, transformative objectives, interventions and approaches that enable their empowerment. There is a pressing need for policy-makers to draw seriously upon ethnographic research to gain insight into the specific, fundamental day-to-day challenges that girls face, and employ 
assessment frameworks such as the WEF to both assess and inform policy around girls' education if the commitment to women's empowerment is genuine.

\section{Notes}

1. Sara Longwe is a teacher and African feminist activist, who has championed women's rights in international courts and has been centrally involved in organisations such as the Zambian Association for Research and Development and FEMNET (The African Women's Development and Communication Network), of which she is currently chairperson, and GRACE (Gender Research in Africa for ICTS and Development). In 2003 Longwe was awarded the African Prize for Leadership by the Hunger Project.

2. I define 'journaling' as the self-reflexive process of documenting daily happenings in a research journal.

\section{References}

Ansell, Nicola. 2002. Secondary education reform in Lesotho and Zimbabwe and the needs of rural girls: Pronouncements, policy and practice. Comparative Education 38: 91-112.

Charmaz, Kathy. 2006. Constructing grounded theory: A practical guide through qualitative analysis. London: Sage.

Charmaz, Kathy. 2008. Grounded theory as an emergent method. In Handbook of constructionist research, ed. Sharlene N. Hess-Biber and Patricia Leavy, 155-70. New York: Guilford.

Dunne, Mairead, Sara Humphries, and Fiona Leach. 2003. Gender and violence in schools. Background paper prepared for the Education for All Global Monitoring Report, 2003/4, Gender and education for all: the leap to equality. Paris: UNESCO.

Edinburgh Global Partnerships. n.d. 2006 projects. http://egp.eusa.ed.ac.uk/2006uganda.htm (accessed July 5, 2006).

Egbo, Benedicta. 2000. Gender, literacy and life chances in Sub-Saharan Africa. Clevedon, UK: Multilingual Matters.

Fiedrich, Marc. 2004. Functional participation? Questioning participatory attempts at reshaping African gender identities: The case of REFLECT in Uganda. In Women, literacy and development: Alternative perspectives, ed. Anna Robinson-Pant, 219-32. London: Routledge.

Freedman, Jane, and Nana Poku. 2005. The socioeconomic context of Africa's vulnerability to HIV/AIDS. Review of International Studies 31: 665-86.

Geertz, Clifford. 1973. The interpretation of cultures: Selected essays. New York: Basic Books.

Geiger, Tinne. 2002. Female education in Sub-Saharan Africa: Importance, obstacles and prospects. Final student paper presentation, University of Aarhus, Denmark. http:// www.ulandslaere.au.dk/Opgavestof/2002/EndeligeOpgaver_2002/

FemaleEducationSubSaharanAfrica_TinneGeiger.pdf (accessed November 19, 2004).

Jones, Shelley K. 2008. Secondary schooling for girls in rural Uganda: Challenges, opportunities and emerging identities. PhD diss., University of British Columbia.

Jones, Shelley, and Bonny Norton. 2009. Sexual health literacy, gender, and HIV/AIDS. In Applied linguistics in the field: Local knowledge and HIV/AIDS, ed. Christina Higgins and Bonny Norton, 155-70. Bristol, UK: Multilingual Matters.

Kakuru, Doris M. 2006. The combat for gender equality in education: Rural livelihood pathways in the context of HIV/AIDS. African Women Leaders in Agriculture and the Environment, AWLAE Series No. 4. Wageningen, The Netherlands: Wageningen University Press.

Kwesiga, Joy C. 2002. Women's access to higher education in Uganda: Uganda's experience. Kampala, Uganda: Fountain.

Lacey, Marc. 2003. For Ugandan girls, delaying sex has economic cost. New York Times, August 18, World section, Africa section. http://www.nytimes.com/2003/08/18/world/forugandan-girls-delaying-sex-has-economic-cost.html?sec=health (accessed July 5, 2006).

Leach, Fiona. 2003a. Learning to be violent: the role of the school in developing adolescent gendered behaviour. [Electronic version.] Compare 33: 385-400. 
Leach, Fiona E. 2003b. Practising gender analysis in education. Oxford: Oxfam.

Leach, F., V. Fiscian, E. Kadzamira, E. Lemani, and P. Machakanja. 2003. An investigative study of the abuse of girls in African schools. London, UK: DFID.

Levinson, B.A., and M. Sutton. 2001. Introduction: Policy as/in practice - A sociological approach to the study of educational policy. In Policy as practice: Toward a comparative sociocultural analysis of educational policy, ed. Bradley Levinson and Margaret Sutton, 1-22. Westport, CT: Ablex.

Longwe, Sara H. 1998. Education for women's empowerment or schooling for women's subordination? Gender and Development 6, no. 2: 19-26.

Luke, Nancy. 2003. Age and economic asymmetries in the sexual relationships of adolescent girls in Sub-Saharan Africa. Studies in Family Planning 34, no. 2: 67-86.

Ministry of Education and Sports (MoES). 1999. National strategy for girls' education in Uganda. Kampala, Uganda: MoES.

Mirembe, Robina. 2004. A safe space for girls. In Gender violence in schools newsletter 1: What is it and why does it happen? Brighton, UK: DFID. http://www.id21.org/education/ gender_violence/indix.html (accessed April 4, 2006).

Mirembe, Robina, and Lynn Davies. 2001. Is schooling a risk? Gender, power relations, and school culture in Uganda. Gender and Education 13: 401-16.

Muriisa, Roberts K. 2006. The AIDS pandemic in Uganda: Social capital and the role of NGOs in alleviating the impact. PhD diss., University of Bergen.

Ndyanabangi, B., W. Kipp, J. Odit, B. Mwijuka, R. Mirembe, and J. Ntozi. 2003. Reproductive health behaviour among adolescents and young adults in a semi-urban district in Uganda. Journal of Health and Population in Developing Countries 28: http:// www.longwoods.com/product.php?productid=17624\&cat=394\&page $=1$ (accessed May 9, 2006).

Nussbaum, Martha C. 2003a. Capabilities as fundamental entitlements: Sen and social justice. Feminist Economics 9, nos. 2-3: 33-59.

Nussbaum, Martha C. 2003b. Women's education: A global challenge. Signs: Journal of Women and Culture in Society 29: 325-55.

Nyanzi, S., R. Pool, and J. Kinsman. 2001. The negotiation of sexual relationships among school pupils in South-western Uganda. AIDS Care 13, no. 1: 83-98.

Okee-Obong, J. 2000. School children and sex networking in Uganda. April 5. http:// www.edc.org/GLG/hiv-impact/hypermail/0046.html (accessed November 6, 2005).

Okware, S., J. Kinsman, S. Onyango, A. Oplo, and P. Kaggwa. 2005. Revisiting the ABC strategy: HIV prevention in Uganda in the era of antiretroviral therapy. Postgraduate Medical Journal 81: 625-28.

Parry, Kate. 2004. Opportunities for girls: A community library in Uganda. In Gender and English language learners, ed. by Bonny Norton and Aneta Pavlenko, 81-93. Arlington, VA: TESOL.

Pitamber, S., and S. Chatterji. 2005. Uganda: Multi-sector country gender profile. Agriculture and Rural Development, North East and South Region (ONAR). African Development Fund Publication No. MULTI SECTOR COUNTRY \#32F8E4.pdf. www.afdb.org/fileadmin/ uploads/afdb/...and.../UG-gender-profile1.pdf (accessed November 6, 2006).

Robeyns, Ingrid. 2006. Three models of education: Rights, capabilities and human capital. Theory and Research in Education 4, no. 1: 69-84.

Robinson-Pant, Anna. 2004. Introduction. In Women, literacy, and development: Alternative perspectives, ed. Anna Robinson-Pant, 1-9. London: Routledge.

Saito, Madoka. 2003. Amartya Sen's capability approach to education: A critical exploration. Journal of Philosophy of Education 37, no. 1: 17-33.

Scheier, Rachel. 2006. 'Carpet grades' are target of Ugandan bias policy. PeaceJounalism. Com, April 30. http://peacejournalism.com/ReadArticle.asp?ArticleID=8673 (accessed July 5, 2006).

Schoepf, Brooke Grundfest. 2003. Uganda: Lessons for AIDS control in Africa. Review of African Political Economy 30: 553-72.

Seel, Amanda, and Gibbard, Amanda. 2000. Mainstreaming gender through sector wide approaches in education: Uganda case study, October, 2000 (electronic version). London: DFID.

Sen, Amartya K. 1999. Development as freedom. New York: Anchor Books. 
Serwadda, David. 2003. Beyond abstinence. Washington Post, May 16, Section A.

Shore, Cris, and Susan Wright, eds. 1997. Anthropology of policy: Critical perspectives on governance and power. London: Routledge.

Sperandio, Jill. 2000. Leadership for adolescent girls: The role of secondary schools in Uganda. Gender and Development 8, no. 3: 57-64.

Stromquist, Nelly P. 1990. Women and illiteracy: The interplay of gender subordination and poverty. Comparative Education Review 34, no. 1: 95-111.

Subrahmanian, Ramya. 2005. Gender equality in education: Definitions and measurements. International Journal of Educational Development 25: 395-407.

Twa-Twa, Jeremiah M. 1997. The role of the environment in the sexual activity of school students in Tororo and Pallisa districts in Uganda. Health Transition ReviewSuppl. no. 7: 67-82.

UNESCO. 2000. The dakarframework for action. Education For all: Meeting our collective commitments. Paris: UNESCO. http://www.unesco.org/education/efa/ed_for_all/dakfram _eng.shtml (accessed October 11, 2003).

UNESCO Institute for Statistics. 2005. Gender parity in secondary education - Are we there yet? Fact sheet no. 5, April. Montreal: UNESCO Institute for Statistics.

UNICEF. 2007. The state of the world's children 2008: Child survival. New York: UNICEF.

United Nations Development Programme. 2005. Human development report 2005: International cooperation at a crossroads; aid, trade and security in an unequal world. New York: United Nations Development Programme.

Unterhalter, Elaine. 2005a. Fragmented frameworks? Researching women, gender, education and development. In Beyond access: Transforming policy and practice for gender equality in education, ed. Sheila Aikman and Elaine Unterhalter, 15-35. Oxford: Oxfam.

Unterhalter, Elaine. 2005b. Moblization, meanings and measures: Reflections of girls' education. Development 48, no. 1: 110-14.

Unterhalter, Elaine. 2006. Global inequalities in girls and women's education: How can we measure progress? Paper prepared for the HDCA conference, 29 August-1 September, in Groningen. www.capabilityapproach.com/pubs/5_3_Unterhalter.pdf?PHPSESSID=86edf 8a26a391444f8943ce590ee486c (accessed March 30, 2007).

Vavrus, Frances. 2005. Adjusting inequality: Education and Structural adjustment policies in Tanzania. Harvard Educational Review 75: 174-200.

World Economic Forum. 2005. Women's empowerment: Measuring the global gender gap. Geneva: World Economic Forum. 